\title{
Using legislative speech to unveil conflict between coalition parties
}

\author{
Henning Bergmann, Bamberg Graduate School of Social Sciences \\ (Corresponding author: henning.bergmann@uni-bamberg.de) \\ Lucas Geese, University of Bamberg \\ (lucas.geese@uni-bamberg.de) \\ Christian Koss, University of Bremen \\ (ckoss@uni-bremen.de) \\ Carsten Schwemmer, University of Bamberg \\ (carsten.schwemmer@uni-bamberg.de)
}

\begin{abstract}
In parliamentary democracies the survival of a government is primarily dependent on its legislative majority. A high level of disagreement across and within government parties can lead to legislative stalemate and early dissolution of the parliament.

This paper provides a new approach to capture legislative conflict dynamically across the electoral term. We use topic modelling and the scaling method Wordscores to estimate the disagreement across government parties in legislative debate over time. We analyse two German coalition governments that were faced with votes of confidence in 2001 and 2005, namely Chancellor Schröder's cabinets composed of Social Democrats and Greens. We assume two specific policy areas ('defence' and 'labour market/social policy') to be substantial in describing the main conflict lines that led to lifethreatening government crises.

Our findings suggest that analysing speech across the electoral term contributes to the understanding of inter-party conflict dynamics. Therefore, this novel time-variant indicator should be considered as an explanatory variable in future research on cabinet survival.
\end{abstract}

Keywords: Cabinet survival, Germany, Legislative conflict, Legislative speech, Topic modelling, Wordscores 
A major threat for the survival of a majority government in parliamentary democracies is its diminishing legislative support. If a considerable number of members of parliament (MP) no longer supports government-initiated bills and amendments, legislative deadlock and the government's inability to act may ensue. Many constitutions allow the prime minister to ask for a vote of confidence in such hard times. If this vote is not supported by a legislative majority, the dissolution of the parliament and early elections are the consequence.

The German Bundestag was faced with two votes of confidence (VOC) in the recent past. In both his incumbent legislative periods (LP), in which he was leading national governments composed of Social Democrats and Greens (1998-2002 and 2002-2005), Chancellor Gerhard Schröder asked for a VOC. Our paper aims to depict policy conflict across the government parties that led to situations where the request of a VOC was the Chancellor's last resort. We outline a novel approach to improve two lacunae of past research on government survival and termination. First, empirical studies include mostly static explanatory variables that do not capture dynamics across the legislative term. Second, they lack appropriate measures of legislative disagreement.

We use novel data on legislative debate to model policy conflict between the cabinet parties. Past approaches measure policy positions at the beginning of a legislative term, typically extracted from expert surveys or content analyses of party manifestos, assuming that this position would remain fixed until the end of a legislative term. Obviously making such assumptions describes a situation which deviates from real world coalition politics. In fact, randomly occurring events such as policy shocks (Laver and Shepsle 1998) can affect the dynamics of increasing inter-party polarization and, equally, incumbents' utility calculations of maintaining or terminating a government (Lupia and Strøm 1995).

We focus our analysis on two salient policy dimensions (defence and labour market/social policy) that, as we assume, mainly caused the two VOC requests. In November 2001 the Chancellor's vote was combined with a policy proposal on the involvement of the armed forces in the war in Afghanistan. The main controversy that led to the 2005 government crisis and early dissolution of the Bundestag in July was caused by far-reaching reforms in the labour and welfare system.

In analytical terms, we rely exclusively on 'text as data' approaches. In order to isolate crucial policy areas of speechmaking, we utilize Structural Topic Models provided in the R package 'stm'. For detecting MPs' speech deviations aggregated by party over time we rely on the 
supervised scaling method Wordscores (Laver et al. 2003) to aggregate speaker positions by party in a one-dimensional space. The large corpus of analysed speech enables the depiction of policy positions across the electoral term for both a general left-right dimension and for the specific policy areas of interest isolated with topic models. Our results suggest that the analysis of legislative speech can contribute to the understanding of inter-party conflict dynamics. This time-variant measure should be incorporated as an independent variable in future cross-country studies on early government termination.

Our paper is structured as follows. First, we review the literature on government survival and work out how this paper contributes to that field of study. Second, we briefly address the shortfalls of previous measures of legislative positions. In the following part, we explain what the analysis of legislative speech can add to the understanding of coalition conflict and why speeches are a valid indicator to measure conflict. Subsequently, we pose theoretical expectations with regard to our empirical analysis. Following this, we discuss methodological aspects and present our findings. The paper concludes with a short discussion.

\section{LEGISLATIVE CONFLICT AND CABINET SURVIVAL}

Initial studies of cabinet stability date back to the 1960s, when fixed attributes such as characteristics of a cabinet itself (such as its type, numeric size, number of parties included, or its ideological cohesion), its institutional constraints and its bargaining environment were linked to the duration (Grofman and Van Roozendaal 1997; Laver 2003). In the 1980s, this 'structuralist' approach was challenged by a stochastic perspective. The underlying assumption was that the fate of an incumbent government was mainly threatened by randomly occurring 'events' such as crises, scandals or natural disasters (Browne et al. 1984, 1986; Cioffi-Revilla 1984; Frendreis et al. 1986). In contrast to the structuralists, the events scholars take a dynamic perspective, assuming that the risk of early termination is not constant over the legislative term but dependent on the presence (or absence) of such critical events. Finally, both the structuralist and the events approach were unified (King et al. 1990) into a coherent and testable framework. Scholars usually combine static and time-variant independent variables to estimate the impact of structural factors and events on the hazard of early government termination (e.g. Warwick 1992, 1994; Schleiter and Morgan-Jones 2009; Saalfeld 2013; Goplerud and Schleiter 2016). These studies are similar in that they solely focus on economic data (e.g. unemployment rates) to capture dynamic processes across the electoral term. At this stage, no appropriate time-varying measures of ideological distance or 
policy conflict between coalition partners exists. A discussion of existing measures will follow in the subsequent section.

Furthermore, our work connects to formal contributions such as Laver and Shepsle's (1996) concept of an equilibrium cabinet. An equilibrium cabinet is defined as a 'cabinet, once it is formed, stays formed because no political actor with the ability to act in such a way as to bring down the cabinet and replace it with some alternative has the incentive to do so' (Laver and Shepsle 1996: 61). However, throughout its incumbency, an equilibrium cabinet may be challenged by different kinds of events or exogenous shocks that can occur randomly and unexpected. Those '[s]hocks may destabilize a cabinet that was previously in equilibrium by shifting key parameters of the government formation environment in ways that were not taken into account when the government was put together' (Laver and Shepsle 1996: 196-197). Laver and Shepsle (1998) identify four relevant types: policy shocks, agenda shocks, decision rule shocks and public opinion shocks. A utility function depicting the incumbent's incentives to maintain or to terminate a government in response to such events is presented in Lupia and Strøm's (1995) game-theoretical model. Lupia and Strøm postulate that incumbent government parties permanently trade off the utility of remaining in office against the expected utilities of reshuffling the government or calling an early election. Several parameters, namely a party's control of seats, initial and post-negotiation shares of power, value of (alternative) coalition partners, post-election prospects, and election- plus negotiation-related transaction costs are used to model the utility calculations. Arguably, an exogenous shock may make a controversial issue more salient, such that the respective policy distance between coalition partners on that issue may influence both the value of (alternative) coalition partners, future negotiation costs of incumbent government parties and the perceived electoral costs of maintaining the coalition.

While potential inter-party conflict is captured to some extent by static explanatory variables such as a government's bargaining duration or the existence of a coalition agreement (Saalfeld 2008), legislative dynamics were not captured in recent empirical modelling. We aim to make a contribution here by mapping policy positions of (government) parties over the legislative term. Our work links to Laver and Shepsle's (1996) assumption that the emergence of a new issue ('policy shock') may destabilize a government's equilibrium and implies potentially more conflict or even the possibility of an early termination. 
Past research of legislative debate was mostly connected to the study of coalition governance. For instance, Martin and Vanberg (2008) studied legislative speeches in Germany and The Netherlands to figure out how MPs communicate to their constituents. However, the link between legislative behaviour and cabinet survival is mostly uncharted territory. Giannetti and Benoit (2009: 14) point out that

[...] the strategic approach highlights the importance of legislative activity as a key factor influencing government termination. [...] There is, however, a relative disjunction between theoretical and empirical work in this area. In part this situation stems from limitations in the models themselves [...]. In part it arises from serious difficulties in obtaining data that would allow rigorous testing of the theories outlined across a larger number of national settings.

This assessment highlights the need of conceptualizing a dynamic measure of legislative conflict to enhance our understanding of coalition conflict and early government termination.

\section{MEASURING LEGISLATIVE POSITIONS}

The measurement of political actors' ideological positions has a long tradition in political science. Common approaches measure each coalition partner's policy position at the beginning of a legislative term, typically extracted from expert surveys (Benoit and Laver 2006; Bakker et al. 2015) or content analyses of party manifestos (Budge et al. 2001), assuming that this position would remain fixed until the end of a legislative term and that the parties’ legislators act unitarily as if they were speaking with one voice.

In addition to expert surveys and manifestos, the analysis of roll-call votes contributes to the measurement of legislative positions. Roll-call votes are very useful to study the dimensionality of policy spaces, prominent examples are given by Poole and Rosenthal (1985) for the U.S. House and Senate and Hix et al. (2006) for the European Parliament. Also, roll-call votes are used to study the voting cohesion of legislative parties (Sieberer 2006). Despite their undisputed benefits in answering questions of legislative dimensionality and party unity, roll-calls are an inappropriate source to track party positions or legislative conflict dynamics across time for two reasons.

First, while some legislatures such as the U.S. Congress publish all votes publicly, roll-call votes are rare events in other legislatures such as the German Bundestag. In all 17 post-war LPs from 1949 to 2013 only 1,938 votes were recorded, with a mean of 114 votes per term 
and a minimum of 24 votes in the fifth LP (Bergmann et al. 2016: 32). Such small sample sizes do not allow the construction of a time-varying measure of the parties' (dis-)agreement, even less when disaggregating the analysis into individual policy areas. The institutional variation in the frequency of roll-calls across legislatures (Hug 2010) aggravates our ambition to construct a dynamic variable on party positions across countries. Second, roll-call votes are usually only a small subset of all votes held in a legislature. For Germany, we know that only 5.2 per cent of the final passage votes on bills in the Bundestag were recorded (citation removed for review). This indicates that decisions to record a vote are to some extent strategic, which means that selection effects may lead to a biased subsample (Carrubba et al. 2006; Hug 2010). Consequently, the real level of conflict may be underestimated in roll-call data. Additionally, the high level of party discipline in voting in the Bundestag as well as in other legislatures (Sieberer 2006) may also dilute potentially existent conflict patterns.

In a nutshell, the analysis of roll-call votes may be fruitful for contextualizing a particular legislative conflict, but does not allow a systematic analysis over time. For this reason we will focus on a different data source that may unveil inter-party conflict beyond legislative voting: the analysis of parliamentary speech.

\section{LEGISLATIVE SPEECH AS INDICATOR OF CONFLICT}

Debate is an essential feature of parliamentary democracy. While speeches may have a deliberative function in democracies (Bächtiger 2014) and enhance the exchange of positions and the persuasion of political opponents, we highlight the coalition managing and voteseeking dimension of parliamentary debate for the purpose of our work. When speaking on the floor, MPs act as agents of their parliamentary party leaderships expressing the parties' position to the coalition partner and to their voters ('position-taking'). Martin and Vanberg (2008) show how parties reconcile the tension between partisan policy commitments and coalition compromises towards the voter using the legislative floor. Shifts in the legislative agenda are also directly expressed in debates. In a dynamic approach Quinn et al. (2010) demonstrate that members of the U.S. Senate are highly responsive to exogenous events such as the Capitol shooting or $9 / 11$, measured by the number of words corresponding to certain topics.

Debate is not only an instrument of party competition but can also reveal intra-party conflicts. Proksch and Slapin (2012) provide a formal model in which legislative debate is part of a delegation game taking place in the public between the poles of backbenchers having 
incentives to deviate from the party line and the party leaders' goal to establish party cohesion and consensus. This relationship between party leaders and backbenchers can cause selection bias as party leaders may try to exclude dissenting MPs for strategic reasons. There is empirical evidence that less floor time is allocated to those MPs who tend to deviate more from the party line (Proksch and Slapin 2015). For methodological reasons, we will not investigate the intra-party dimension of conflict and, instead, will focus exclusively on the conflict between coalition parties. Therefore, we assume that parties are unitary actors and that MPs speak as delegates of their party.

For calculating aggregated party positions over time the analysis of debates offers some crucial advantages compared to roll-call votes. As discussed, we define legislative speechmaking as a strategic instrument of party competition to express positions to voters, the coalition partner and the media. Hence, speech is a valid indicator for the positioning of parties in the political space. In addition, three methodological aspects strengthen our choice. First, speech analysis reduces the selection bias that is attributed to roll-call votes as considerably more observations are available. Second, several distinct policy areas are covered by speeches to a similar extent across time, which allows us to estimate policyspecific conflict. Third, the use of an automated scaling method allows us to depict conflict in a more fine-grained way than data obtained from mostly dichotomized voting procedures.

\section{CASES AND THEORETICAL EXPECTATIONS}

We analyse legislative conflict within the two coalition governments under Chancellor Schröder from 1998 to 2005. Our case selection is driven by both theoretical and pragmatic reasons. As the cleaning and preparation of the data corpus was a highly challenging task and as our endeavour is more of explorative nature, we restrict the analysis to two cases. Both governments are comparable by party composition (Social Democrats and Greens), government type (minimal connected winning coalition) and size. In the 1998 election the coalition parties received 345 of 669 seats (51.6 per cent; majority threshold 335 seats) and in the 2002 election 306 of 603 seats (50.7 per cent; majority threshold 302 seats). These numbers show that a relatively small number of deviating votes from individual MPs were sufficient to undermine the government's majority status (11 for 1998-2002 and 5 for 20022005).

However, the strategic nature of the VOC request varies between the analysed periods. From a theoretical perspective, a 'true' VOC can be seen as an instrument of agenda control that 
gives the PM substantial influence over policy outcomes, especially when combining the vote with an important policy motion (Huber 1996). 'False' or 'dissolution-oriented' VOCs (Niclauß 2007), by contrast, are primarily used by the MP to enforce the early dissolution of the Bundestag for electoral reasons. Scholars interpret Schröder's second VOC in 2005 as a mainly strategic choice to force the dissolution of the Bundestag, while he requested a 'true' VOC in terms of agenda control and disciplining the parliamentary party groups of the coalition in 2001 (Hönnige 2009).

With regard to our theoretical expectations we assume that all relevant political actors (1) care about the three traditional objectives of party behaviour, policy, office and votes (Strøm 1990), and (2) that they are responsive to both endogenous outcomes such as the state of the economy (Hellwig 2012) and exogenous shocks such as public opinion changes, a terrorist attack or the outbreak of a war (Quinn et al. 2010). Such events can potentially shift positions of the government parties on salient policy dimensions in a substantial way or, put differently, bring a government out of its initially negotiated equilibrium (Laver and Shepsle 1996). As a consequence, political actors may adjust their positions in response to these events and changes should be reflected in legislative debate.

The following hypotheses are deduced on the basis of one main consideration, that is, did one (or more) exogenous shock emerge in the corresponding legislative term which potentially shifted party positions in the salient policy areas?

\section{The first Schröder cabinet (1998-2002)}

In November 2001 Chancellor Schröder combined a VOC for the first time with a policy proposal on the involvement of the armed forces of Germany in the war in Afghanistan as a consequence of the 9/11 terrorist attacks and the subsequent activation of NATO's mutual defense clause. Therefore, the issue of a military intervention in Afghanistan is clearly an exogenous policy shock with the potential to upset the previously established coalition equilibrium. ${ }^{1}$ Leading the first coalition in history involving the Greens, Schröder used a 'true' VOC as an instrument to enforce discipline among the MPs of the coalition parties (Hönnige 2009). In this case, the inspection of legislative voting data is helpful to gain an insight into the conflict line structure. In particular, a considerable number of MPs of the Greens deviated in defence-related roll-call votes from the coalition line previous to the VOC. $^{2}$ This lack of voting unity could be related to the strong pacifist stance on foreign and 
defence policy of the Greens being a consequence of the parties' roots in ecological-pacifist movements in the 1980s.

The involvement in the War in Afghanistan, however, was not the only controversial defence policy issue in that period. Even earlier in the LP, the German involvement in the Kosovo War, which began in 1998, was also a highly controversial issue for the Greens. Beginning in March 1999 and ending in June the same year, the NATO bombing in Yugoslavia (Operation Allied Force) was an emotionally charged issue within the Greens and even turned out to be violent: In May 1999 the Minister for Foreign Affairs, Joschka Fischer (Greens) was attacked with a paint bomb at a special party congress of the Greens held to approve Germany's military involvement in the Kosovo War.

Thus, during the LP 14 there were indeed two considerable exogenous shocks in a highly salient policy area for one of the coalition partners. Consequently, we expect to find a strong policy conflict line in defence-related debates between the coalition partners as a consequence of anti-interventionist policy positions expressed in speeches of the Greens (Hypothesis 1). Second, with regard to the timing of the events we expect the conflicts to increase in the second quarter of 1999 (Kosovo) and after September 2001 (9/11, Afghanistan) as the overall party positions towards military interventions drifted apart (Hypothesis 2).

\section{The second Schröder cabinet (2002-2005)}

Conflicts within the SPD regarding social policy reforms and the party's poor electoral performance at second order elections were substantial for the early termination of Schröder's second cabinet forced by his 'dissolution-oriented' VOC. The 'Hartz' labour market reforms, named after the head of the commission, Peter Hartz, were incrementally introduced from 2003 to 2005 and part of the 'Agenda 2010' project. With this project Chancellor Schröder attempted to fundamentally reform the German labour market and stimulate economic growth to reduce the high unemployment rate, which was the most important problem for German citizens at that time. Critics blame the SPD for departing with these reforms from its working class roots towards providing a more neoliberal agenda. Indeed, the SPD lost all second order elections during the legislative period. Finally, the significant drop in the 2005 state election in North Rhine-Westphalia, home territory of the SPD, was the trigger for Schröder to force early elections by asking for a ‘false’ or ‘dissolution-oriented’ VOC in July 2005.

For this cabinet it is more difficult to identify an external shock that was clearly exogenous to the government actions. Presumably, the exceptional losses of the SPD in state elections 
(from 2002 to 2005 all Red-Green state governments were voted out of office) were to some extent outside the control of the federal government. The stepwise introduction of the labour market reforms injected displeasure into the party that was constantly increasing in both party base and among the electorate as the reforms pushed the party, to some extent, away from traditional Social Democratic positions. As mentioned before, the disruption peaked when the party lost the important state election in North Rhine-Westphalia in May 2005.

Based on these considerations, and contrary to our first case, we do not expect to find that time-variant speech differences between SPD and Green MPs indicated severe intra-coalition conflicts in the area of labour market and social policies in LP 15 (Hypothesis 3). Instead, the reasons for Schröder's decision to ask for the VOC arise mainly from intra-party conflicts within the SPD. These conflicts are not examined in this paper.

\section{DATA AND METHOD}

In order to test these hypotheses empirically, a prerequisite to, first, categorize legislative debate into policy areas, and second, to measure ideological positions from parliamentary speeches. Given that we are dealing with several thousand speeches in each legislative term (see Table 1), we rely on automated methods of textual analysis. In a first step, we categorize debates into policy areas, relying on structural topic models (Roberts et al. 2014; Lucas et al. 2015). In a second step, we then estimate area-specific policy positions from speeches assigned in the previous step to the policy areas 'defence' (LP 14) and 'labour market and social policy’ (LP 15), using the well-established scaling technique Wordscores (Laver et al. 2003).

In order to apply automated text procedures, the raw textual data first was processed by applying several cleaning procedures. First, we removed all texts by the Presidents of the Bundestag, secretaries, ministers and the Chancellor. Following recommendations from Lauderdale and Herzog (2016), we also removed texts with less than 50 words, as these are very likely to only represent short interruptions rather than actual speeches. Table 1 shows a comparison for each legislative period between raw and processed data.

\section{[Table 1 about here]}

We define debates as all speeches that were made during the course of one agenda item in the Bundestag's minutes, so-called 'Tagesordnungspunkte'. It becomes apparent that cleaning steps reduce the corpus size for each term significantly, but the remaining datasets still 
include sizeable amounts of text. In LP 14, for instance, a corpus of almost 13,000 speeches remains, which were held by 660 different speakers. In a final step, we stemmed all texts and removed stop words, such that terms like 'family' and 'families' are reduced to one single feature and words without substantial meaning, like 'the' or 'and' are removed from all texts.

\section{Identifying policy areas using structural topic modelling}

To categorize debates into different policy areas, a structural topic model (Roberts et al. 2014), STM, was fitted to each corpus, where we combined texts of all speakers for each debate. ${ }^{3}$ Topic models allow for automatically discovering latent topics from text documents, where a topic can be understood as a set of words representing interpretable themes and documents are represented as a mixture of topics. As an example, a specific debate contains proportions for different topics and could mostly be capturing a topic 'inner security' with a proportion of 60 per cent, but to a lesser extent also 'foreign policy', 30 per cent and 'other' topics, 10 per cent. While topic models provide a very helpful method for dimensionality reduction, a disadvantage of topic models is that the number of topics must be chosen in advance by the analyst. As for the purpose of this work, a model for twenty topics was fitted to each corpus. We decided to assume a similar number of general topics to be discussed in the Bundestag as used in established coding schemes such as the Policy Agendas Project. In order to finally categorize debates into policy areas, we rely on the estimates of our topic models. We use the highest topic proportion to assign a debate to a certain policy area. In addition to representing debates as distributions of topics, STM allows the inclusion of document-specific covariates to affect both document-topic proportions and word distributions over topics. We draw on this feature to let topic proportions vary across the electoral term. The general fit and the distribution of the extracted topics will be discussed in the results section.

\section{Methods of textual scaling}

Automated scaling techniques, that is, the ideological positioning of political actors on a numerical spectrum between two extremes (i.e. left vs. right), are frequently used methods to estimate from speeches the distances between party policies. The menu of scaling techniques includes unsupervised techniques, such as Wordfish (Slapin and Proksch 2008) and Wordshoal (Lauderdale and Herzog 2016), whose estimation of policy positions cannot be influenced by the researcher (hence the label unsupervised). In contrast, supervised techniques, such as Wordscores (Laver et al. 2003), allow us to estimate positions on a pre- 
defined policy scale. This distinction is crucial for our choice of the Wordscores method. Given its explorative nature, unsupervised scaling methods are very useful for discovering latent semantic dimensions underlying a collection of texts (Grimmer and Stewart 2013). However, the dimensions extracted are not necessarily the kind of dimensions empirical researchers have in mind, that is, it should not be assumed that the identified dimension is, for example, a political left-right continuum. In fact, as Grimmer and Stewart explain, the latent dimension identified may be due to other differences in word usage (for example the opposition-government divide) and thus may not be of interest to the researcher. ${ }^{4}$

Wordscores, by contrast, needs supervision in the sense that, in order to measure the unknown positions of text documents (virgin texts), analysts must have at least two reference texts with a priori knowledge about their positions on a pre-defined policy dimension. By comparing the word usage in the virgin text to that in the reference texts, the Wordscores algorithm can then estimate the policy positions of the virgin texts on the pre-defined policy dimension (determined by the scores of the reference texts). Given that we are interested in a priori policy dimensions, Wordscores is the more appropriate method for the research question at hand. Moreover, extant research has shown convincingly that Wordscores provides valid and reliable estimates of political actors' policy positions, whether these are for individual MPs (Laver and Benoit 2002; Bernauer and Bräuninger 2009; Bäck and Debus 2016), Ministers (Giannetti and Laver 2005), presidential candidates (Laver et al. 2006) or collective political parties (Laver et al. 2003; Hjorth et al. 2015).

We follow the example of Bäck and Debus (2016) and use the texts of party manifestos before and after each analysed legislative term as reference texts to score speeches in the respective policy areas identified with the structural topic model. ${ }^{5}$ Reference scores were taken from the Comparative Manifestos Project (CMP; Volkens et al. 2017) and are provided in Table 2. As reference values for party positions in the policy dimension of defence, we rely on the readily available CMP item 'intpeace', which summarizes each manifesto's negative mentions of military interventions (per105) and mentions of belief in peaceful means of solving international crises (per106). The assumption is that more of those mentions indicate stronger anti-interventionist policy positions. As reference values for party positions in the labor/social policy dimension we created our own welfare index based on the CMP items by subtracting from mentions of welfare state limitation (per505) positive mentions of social equality (per503) and welfare state expansion (per504). Higher values on this index indicate policy positions in favour of welfare state retrenchment. 


\section{[Table 2 about here]}

\section{RESULTS}

In this section we first present the results from the topic models that we used to identify the relevant speech in the policy areas of interest. Subsequently, our substantial results regarding the party positions based on the Wordscores estimations will be discussed.

\section{Identifying the relevant topics}

Table 3 shows stemmed FREX terms (Lucas et al., 2015) which are both frequent (FR) as well as exclusive (EX) for each of the twenty topics per corpus for both policy areas of interest. ${ }^{6}$ The FREX terms show that the two general areas of interest, which we labelled 'defence' for LP 14 and 'social and labour market' for LP 15, are captured reasonably well according to the assigned terms. The 'defence' policy area in LP 14 consists of two subtopics, which relate, according to the extracted terms, to an 'international' and to an 'interior' dimension of defence policy. The 'international defence' topic can be described by several country names (i.e. Afghanistan, Kosovo, and Yugoslavia) and terms such as 'war', 'terrorism', or 'human rights', while the 'interior defence' topic contains mostly terms which are related to the German armed forces, Federal Ministers of Defence (Volker Rühe and Rudolf Scharping) and further terms capturing defence polity. For LP 15 we also find that the extracted terms fit the 'social and labour market' policy area reasonably well. Many relevant key terms such as 'labour market', 'pensions', 'unemployment', and 'Hartz' (which relates to both Peter Hartz as a person and his suggested labour market reforms) were extracted from the data corpus.

\section{[Table 3 about here]}

For the distribution of topics, we find, first, that both our policy areas of interest are frequently discussed in the German Bundestag. In LP 14 the defence-related topics constitute around six per cent of the total amount of debate (rank six out of all 20 topics). Labour and social policy-related topics constitute around nine per cent of parliamentary debate and, thus, are the second most discussed topic in LP 15. This finding is not surprising as these substantial policy areas are expected to be discussed during the entire legislative term. Second, we incorporated the dates of debates to discover how proportions of policy areas vary over time. The proportion estimates for the two topics of interest over time in Figure 1 reveal two interesting facts. First, the amount of debate related to defence/international topics in LP 
14 is clearly correlated to the 9/11 terror attacks, as the top depiction A shows, with a peak in the fall of 2001. This finding indicates a shift in the parliamentary agenda due to an exogenous shock and the increased salience of defence policy. Second, the bottom depiction C shows a slight decline of speech related to social and labour market issues over time in LP 15. This finding might indicate that the dispute about the controversial labour market reform did not dominate the legislative agenda or was not fought between the coalition parties in legislative debates. Both interpretations meet our theoretical expectations.

[Figure 1 about here]

\section{Policy position differences in defence-related speech in the first Schröder Cabinet}

Figure 2 shows how the estimated Wordscores positions of speeches given in the policy domain of defence distribute across the major parties in LP 14 in the form of boxplots. Overall, the estimated positions have a good face validity in tendency, given that speeches of the two small left-wing parties (Greens and Left) have more anti-interventionist positions, while the SPD's and the two centre-right parties' MPs express less anti-interventionist positions.

\section{[Figure 2 about here]}

In Figure 3 we present the government parties' positioning in the defence domain across the electoral term. Instead of displaying absolute aggregated party positions we calculate the difference between both parties for an intuitive interpretation. Also, we show the positions as smoothed line charts (top depiction) and in quarterly intervals (bottom depiction). Indeed, we find increasing levels of difference in legislative debate coinciding with the start of the NATO operation in 1999. This disagreement may be caused by SPD MPs generally speaking in favour (pro-militarist) of the German involvement in military interventions while Green MPs represent more positions that reject interventions. It takes approximately one year until the distance of both parties' positions converges to its initial level. In the last quarter of 2001 the disagreement increases again, which can plausibly be related to the 9/11 attacks and the following War in Afghanistan.

\section{[Figure 3 about here]}

Overall, our findings for LP 14 show that our approach is able to capture both the inter-party Kosovo conflict and the conflict that arose from the 9/11 terror attacks reasonably well. First, we find empirical evidence for the emergence of an exogenous shock which increased the 
legislative salience of a topic as indicated by the amount of defence-related debate after 9/11. Second, both the Kosovo and the Afghanistan issue led to increased policy disagreement between both government parties. These findings are in line with both postulated hypotheses. As Schröder combined the VOC in November 2001 with a policy proposal on the involvement of the armed forces in the War in Afghanistan this finding suggests that the analysis of speech can serve as an early-warning system to detect a severe inter-party conflict which severely threatened the government's survival.

\section{Policy position differences in social/labour-related speech in the second Schröder Cabinet}

Figure 4 displays the same visualization of party speakers' policy positions in the labour market and social policy domain in LP 15. Similarly, these estimation results show high face validity in tendency, given that speakers from the Greens, and to a lesser degree from the SPD, express the most favourable positions towards welfare state expansion, while speeches from the CDU/CSU and the FDP express positions more strongly in favour of welfare state retrenchment.

[Figure 4 about here]

Figure 5 replicates the estimation described in the previous paragraph for Schröder's second government which terminated early due to the successful VOC in July 2005. We expected that the labour market ('Hartz') reforms in combination with devastating results at second order elections mainly caused conflict within the SPD. Consequently, levels of inter-party conflict should be lower compared to the previous case. The positional differences across time in Figure 5 suggest that the level of inter-party conflict in labour market and social policy issues reached its maximum in the first quarter of 2005 and decreased afterwards. Though we find variation in conflict across time, increased levels of conflict do not coincide with the VOC request. In general, the results for LP 15 should be interpreted with more caution as the content of social policy is quite broad. The extracted FREX terms indicate that speech on topics such as business, healthcare, or pensions is also included in this dimension. It is possible that the inter-party variation is driven more by these topics than the labour market reforms.

\section{[Figure 5 about here]}

In summary, it can be stated that our empirical evidence does not contradict the interpretation of Schröder's second VOC being, in contrast to the first one, strategic and 'dissolution- 
oriented'. Neither do the topic proportions indicate an increase in the salience of social and labour market policy across the term nor do the parties' positions indicate a policy conflict being at its peak when Schröder asked for the vote. Overall, this evidence corresponds to our expectations postulated in the third hypothesis.

\section{CONCLUSION}

Our work contributes to the research on coalition governments and legislative studies by offering a novel approach using speech to capture party positions across the electoral term. Thus far, time-varying measures on legislative disagreement between coalition parties were not incorporated in studies dealing with the explanation of early government termination.

To close this gap we estimated policy-specific positions for the incumbent parties of two German coalition governments whose survival were threatened by two votes of confidence which varied in their strategic nature. We defined two policy areas to be substantial in describing the main conflicts that caused the votes: defence and labour market/social policy. We used structural topic models to identify the relevant speech in the data corpus. Subsequently, we applied Wordscores to scale party positions across the electoral term. The results suggest that our novel approach works quite well, especially in the case of exogenous events that can plausibly be linked to inter-party conflict structures.

Nevertheless, there are some drawbacks which have to be addressed by future studies. First, our explorative analysis is restricted to only two German cases. Future research should expand this number and also calculate positions for non-conflictual. Second, the definition of salient policy areas might not be as straightforward for other cases as it was in the current study. An alternative would be to estimate the overall right-left differences between government parties across the electoral term. While this approach is obvious it raises some conceptual issues. In the analysis of the complete speech corpus various topics are mixed up and inter-party differences in a substantial policy area might be balanced by speech in less salient areas.

Though it is a challenging endeavour to prepare this complex corpus of data for appropriate empirical analyses, our new approach of speech analysis offers scholars new perspectives to study legislative dynamics and to link corresponding data to existing datasets on government survival. The analysis of time-variant data on political positions is a step forward for testing complex theoretical models of strategic government termination, such as Lupia and Strøm's 
(1995) model. Thus, we want to motivate researchers to make use of the methods in the emerging field of automated text analysis to contribute to such endeavours. 
TABLES AND FIGURES

\begin{tabular}{|lcccc|}
\hline Legislative Period & Debates & Speakers & Speeches & Words \\
\hline 14 & 1520 & 770 & 54322 & 14197484 \\
\hline 14 (processed) & 1159 & 660 & 12804 & 3378491 \\
\hline 15 & 1189 & 653 & 36347 & 9637845 \\
\hline 15 (processed) & 879 & 583 & 8391 & 2405896 \\
\hline
\end{tabular}

Table 1: Data used in analyses. 


\begin{tabular}{|l|c|c|c|c|}
\hline Party manifesto & $\begin{array}{c}\text { Intpeace } \\
1998\end{array}$ & $\begin{array}{c}\text { Intpeace } \\
2002\end{array}$ & $\begin{array}{c}\text { Welfare } \\
\text { index 2002 }\end{array}$ & $\begin{array}{c}\text { Welfare } \\
\text { index 2005 }\end{array}$ \\
\hline CDU/CSU & 0.353 & 0.228 & -5.932 & -5.020 \\
\hline FDP & 2.056 & 0.252 & -1.615 & -5.848 \\
\hline SPD & 1.202 & 1.366 & -8.386 & -13.142 \\
\hline GREENS & 3.526 & 2.651 & -13.194 & -17.461 \\
\hline LEFT & 4.738 & 6.517 & -18.247 & -20.593 \\
\hline
\end{tabular}

Table 2: Reference values taken from the Comparative Manifesto Project (CMP). 


\begin{tabular}{|c|c|}
\hline LP 14 & FREX terms \\
\hline Defence/International & $\begin{array}{l}\text { Kosovo, Macedonia, Milošević, terrorism, NATO, Afghanistan, war, Yugoslavia, OSCE, } \\
\text { nations, united, Russia, military, human rights, peace, stability pact, Balkan, foreign minister, } \\
\text { foreign policy, refugee, humanitarian, foreign, states, human rights violations, Chechnya, } \\
\text { region, Israel }\end{array}$ \\
\hline Defence/Interior & $\begin{array}{l}\text { Bundeswehr (German armed forces), Scharping, minister of defence, soldiers, conscription, } \\
\text { armed forces, parliamentary ombudsman for the armed forces, defence budget, Breuer, } \\
\text { defence, civil, security policy, service, military, equipment, operation, army, troops, federal } \\
\text { minister, leadership, defence committee, reform of the armed forces, Rühe, tasks }\end{array}$ \\
\hline LP 15 & FREX terms \\
\hline $\begin{array}{l}\text { Social and Labour } \\
\text { Market }\end{array}$ & $\begin{array}{l}\text { employee, dismissal protection, craft, labour market, unemployment, unemployed person, } \\
\text { unions, apprentice position, Mittelstand (small and medium-sized businesses), Clement, } \\
\text { employer, healthcare, operational, employment, company, pension, patient, unemployed, } \\
\text { pension insurance, pensioner, Hartz, apprenticeship, jobs, health insurance, dues, labour } \\
\text { market policy, statutory, participation, health insurance funds }\end{array}$ \\
\hline
\end{tabular}

Table 3: Topics and FREX terms in policy areas of interest (translated; multiple similar mentions were pooled). 

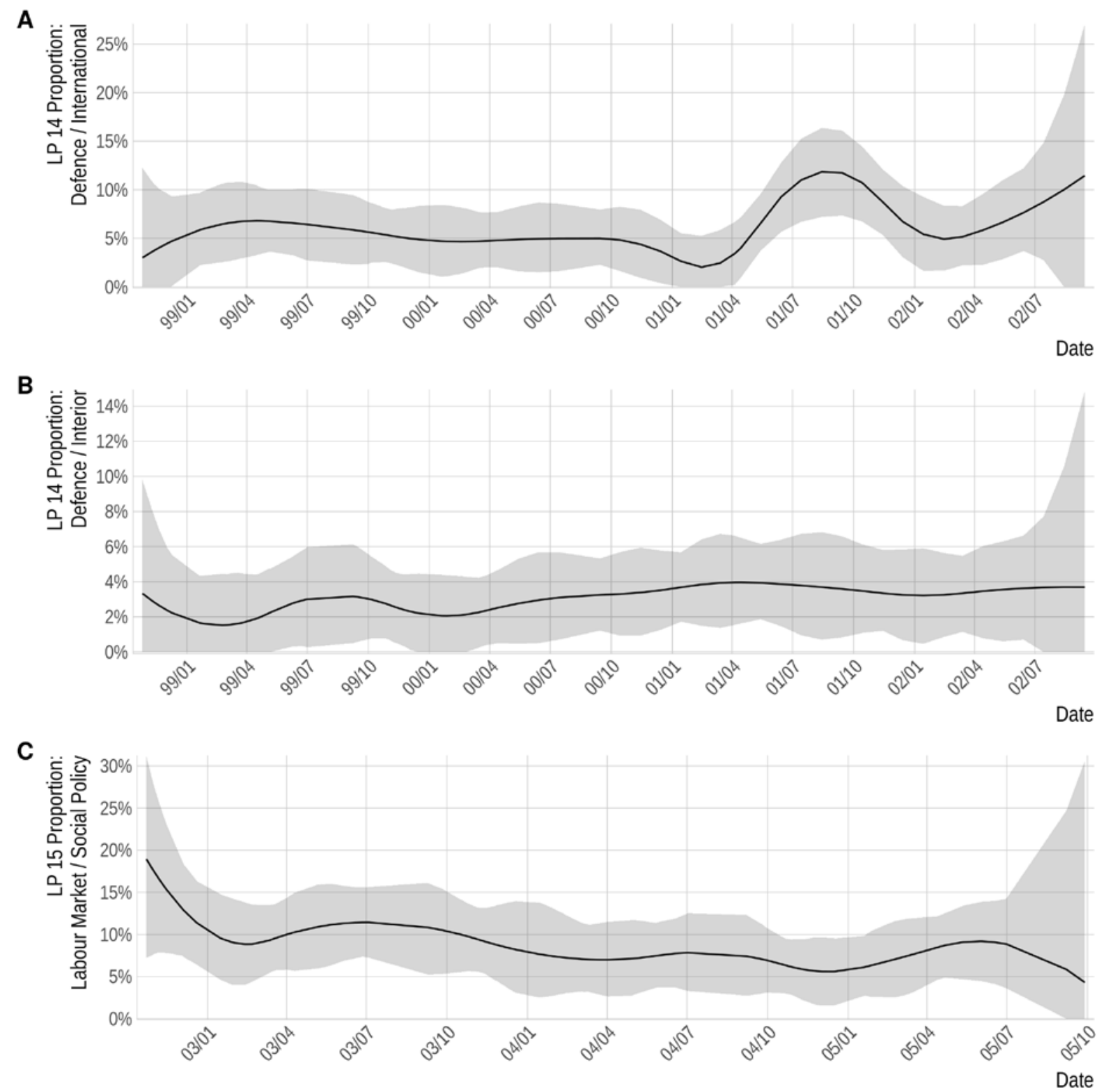

Figure 1: Topic proportions of policy areas of interest across the electoral term. 


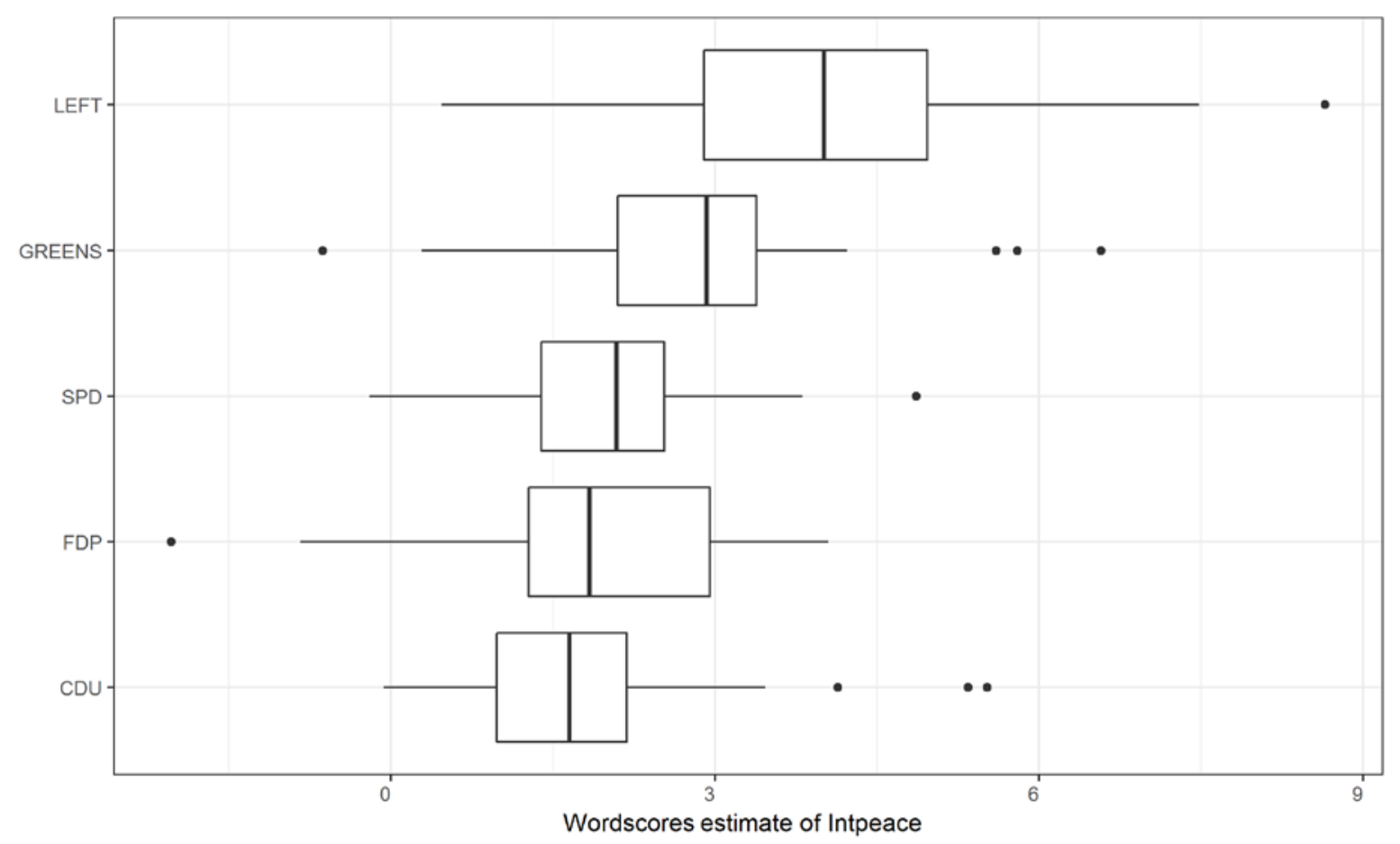

Figure 2: Aggregated positions of parliamentary parties’ MPs over time, defence policy, LP 14 (Wordscores estimation). 

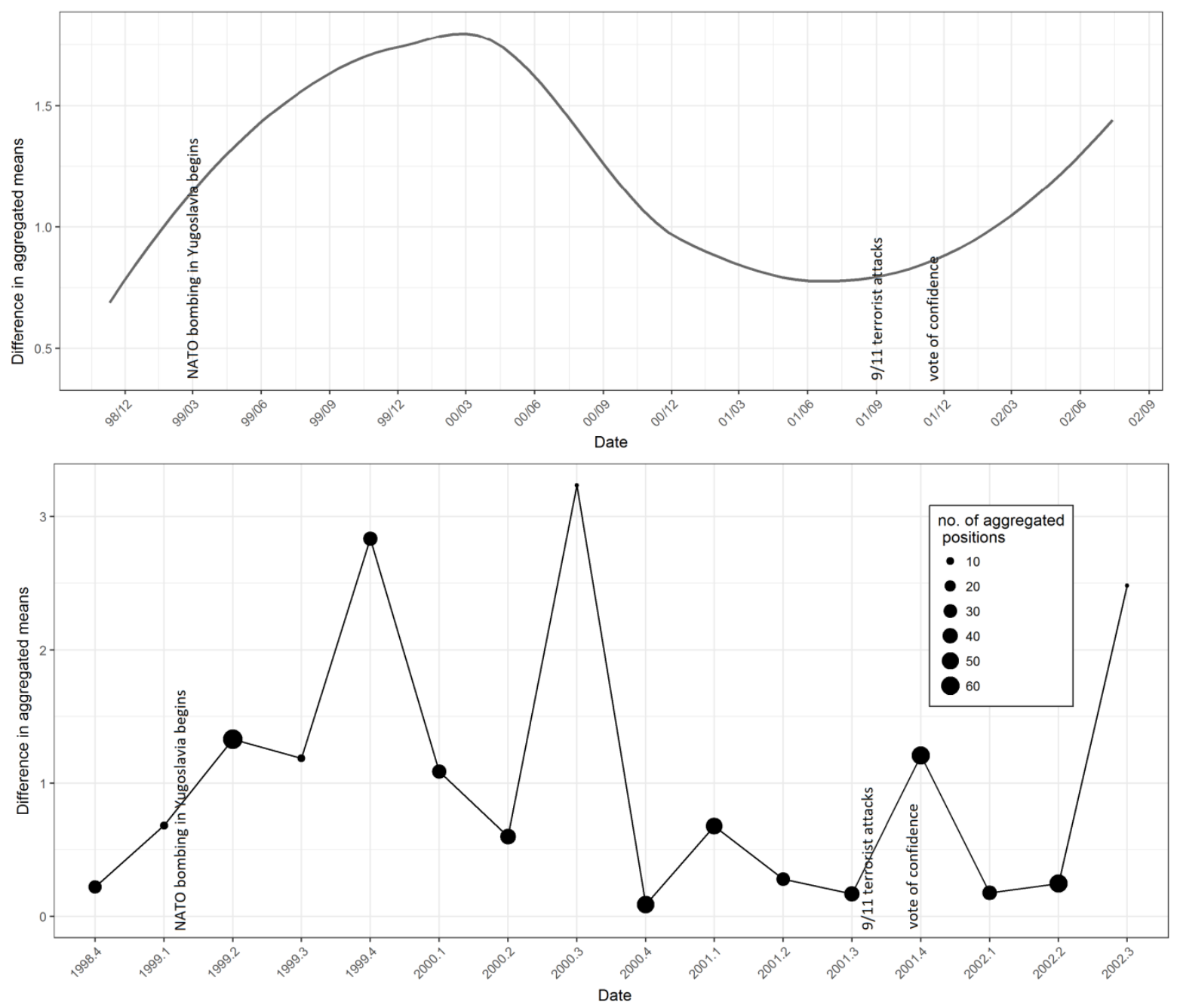

Figure 3: Aggregated difference of SPD and Greens MPs positions over time, defence policy, LP 14 (Wordscores estimation). 


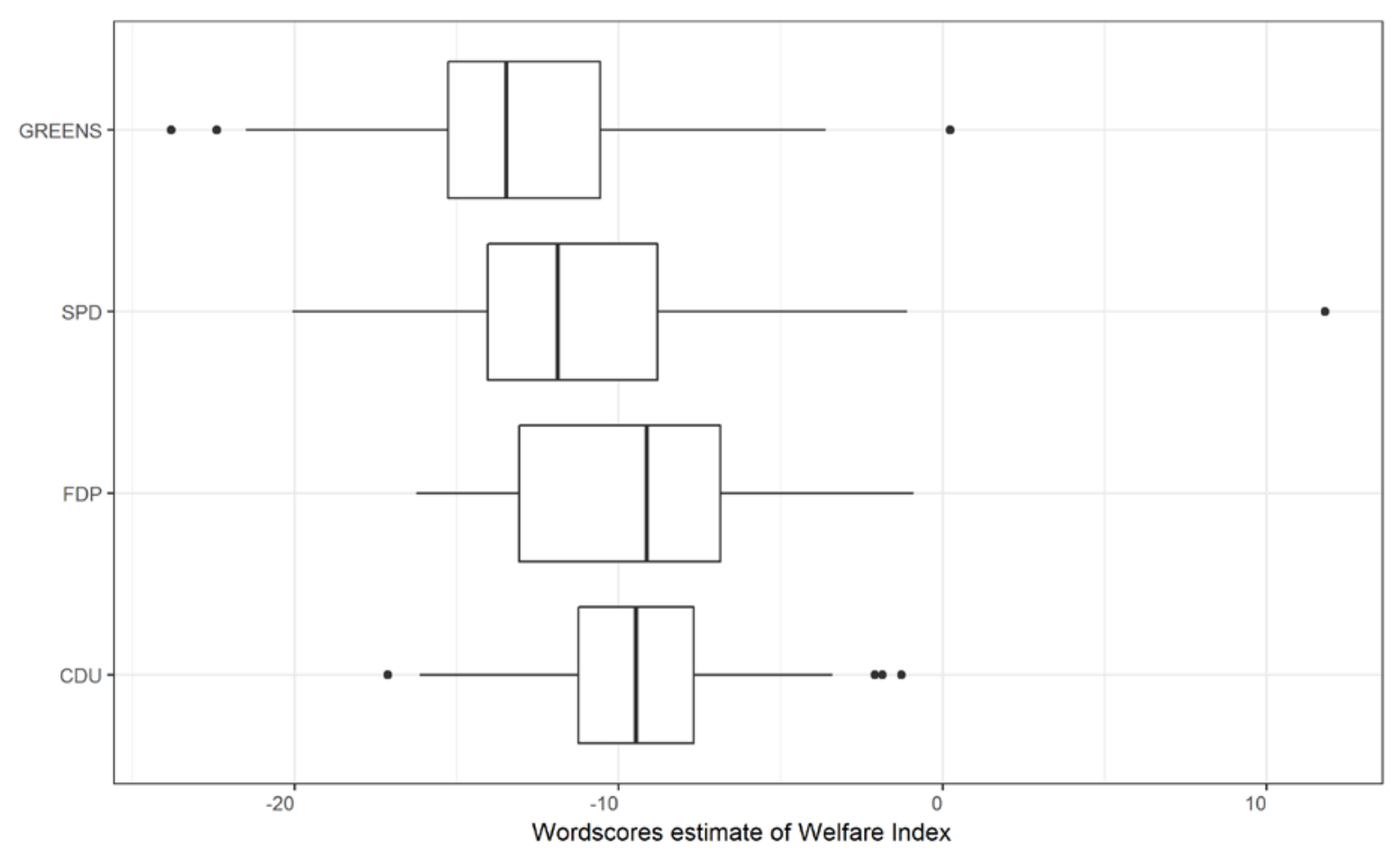

Figure 4: Aggregated positions of parliamentary parties' MPs over time, labour market and social policy, LP 15 (Wordscores estimation). 

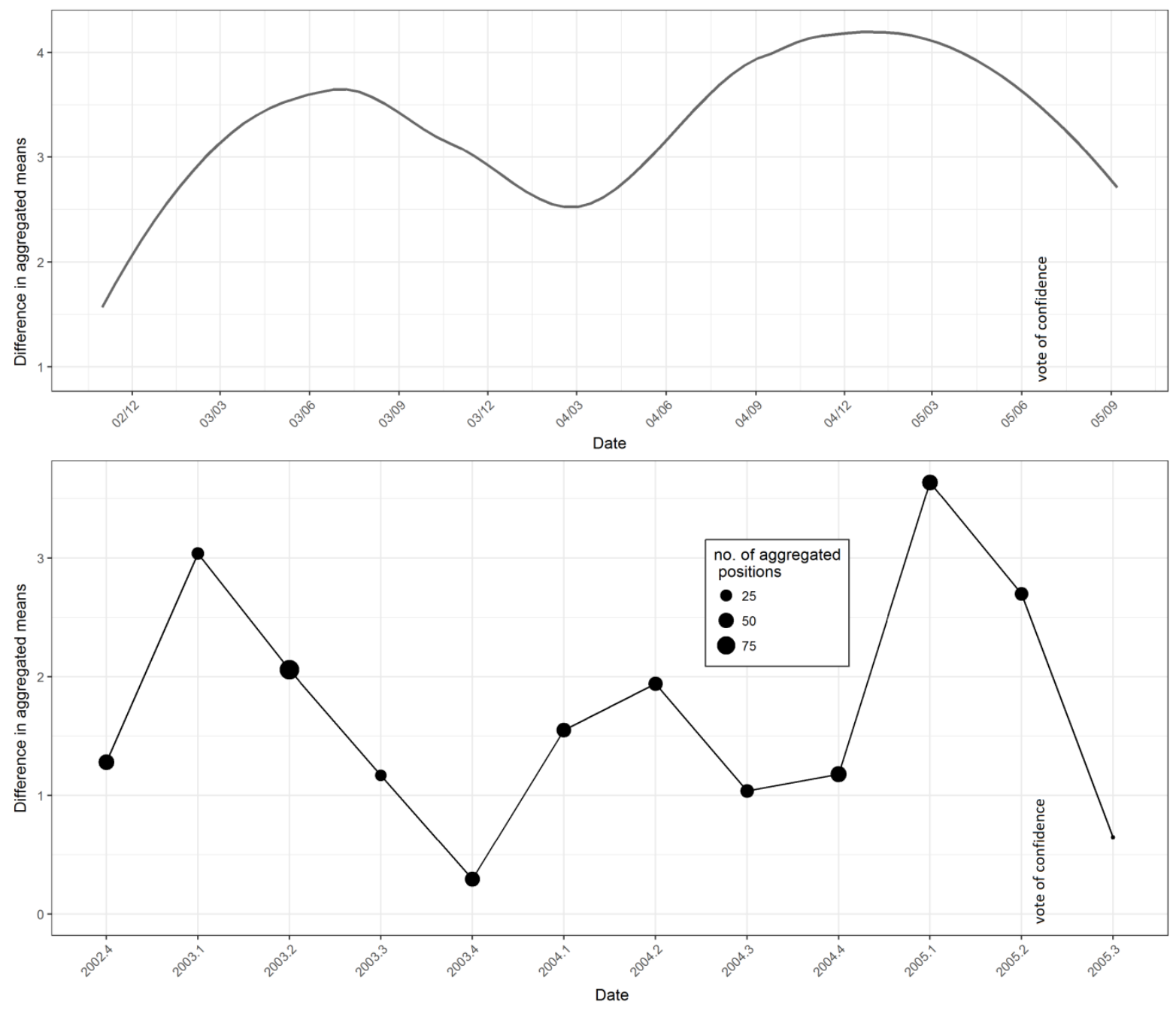

Figure 5: Aggregated difference of SPD and Greens MPs positions over time, labour market and social policy, LP 15 (Wordscores estimation). 


\section{NOTES}

1 This evaluation is also supported by a qualitative examination of newspaper articles from 1999. Many journalists considered a break-up of the coalition to be likely due to heavy interparty quarrels.

2 We used the Agreement Index (Hix et al. 2006) and a dataset on roll-call votes (Bergmann et al. 2016) to compute the legislative cohesion of the coalition parties. In votes on defenserelated topics Green MPs show a relatively low voting cohesion of 0.833 compared to a number of 0.945 for all votes. An Agreement Index value equal to 1 indicates that all MPs vote as a bloc and a value equal to 0 indicates that all MPs are equally divided between the voting options.

3 We used the R package 'stminsights' to validate our structural topic model (Schwemmer 2018).

4 For this reason, an inspection and validation of most discriminating words of the extracted dimension is of utmost importance. In fact, we experimented with unsupervised scaling methods, but dismissed them in the end, because the extracted dimension pointed rather to an opposition-government divide, than to an ideological one.

5 Using manifestos before and after the legislative term is supposed to control for any change in vocabulary over the electoral term.

6 FREX terms for the remaining topics are listed in Appendix A. 


\section{REFERENCES}

Bächtiger, A. (2014), 'Debate and Deliberation in Legislatures', in K. Strøm, T. Saalfeld, and S. Martin (ed.), The Oxford Handbook of Legislative Studies. (Oxford: Oxford University Press): $145-66$.

Bäck, H. and Debus, M. (2016), Political Parties, Parliaments and Legislative Speechmaking (New York: Palgrave Macmillan).

Bakker, R., de Vries, C., Edwards, E., Hooghe, L., Jolly, S., Marks, G., Polk, J., Rovny, J., Steenbergen, M. and Vachudova, M. A. (2015), 'Measuring party positions in Europe: The Chapel Hill expert survey trend file, 1999-2010', Party Politics, 21(1): 143-52.

Benoit, K. and Laver, M. (2006), Party Policy in Modern Democracies (London: Routledge).

Bergmann, H., Bailer, S., Ohmura, T., Saalfeld, T. and Sieberer, U. (2016), 'Namentliche Abstimmungen im Bundestag 1949 bis 2013: Befunde aus einem neuen Datensatz', Zeitschrift für Parlamentsfragen, 47(1): 26-50.

Bernauer, J. and Bräuninger, T. (2009), 'Intra-Party Preference Heterogeneity and Faction Membership in the 15th German Bundestag: A Computational Text Analysis of Parliamentary Speeches', German Politics, 18(3): 385-402.

Browne, E. C., Frendreis, J. P. and Gleiber, D. W. (1984), 'An "Events" Approach to the Problem of Cabinet Stability’, Comparative Political Studies, 17(2): 167-97.

Browne, E. C., Frendreis, J. P. and Gleiber, D. W. (1986), 'The Process of Cabinet Dissolution: An Exponential Model of Duration and Stability in Western Democracies', American Journal of Political Science, 30(3): 628-50.

Budge, I. et al. (2001), Mapping Policy Preferences: Estimates for Parties, Electors, and Governments 1945-1998 (Oxford: Oxford University Press).

Carrubba, C. et al. (2006), 'Off the Record: Unrecorded Legislative Votes, Selection Bias and Roll-Call Vote Analysis’, British Journal of Political Science, 36(4): 691-704.

Cioffi-Revilla, C. (1984), 'The Political Reliability of Italian Governments: An Exponential Survival Model’, American Political Science Review, 78(2): 318-37.

Frendreis, J. P., Gleiber, D. W. and Browne, E. C. (1986), 'The Study of Cabinet Dissolutions in Parliamentary Democracies’, Legislative Studies Quarterly, 11(4): 619-28.

Giannetti, D. and Benoit, K. (2009), 'Intra-party politics and coalition governments in parliamentary democracies', in D. Giannetti and K. Benoit (ed.), Intra-party Politics and Coalition Governments. (London/New York: Routledge): 3-24.

Giannetti, D. and Laver, M. (2005), 'Policy Positions and Jobs in the Government', European Journal of Political Research, 44(1): 91-120.

Goplerud, M. and Schleiter, P. (2016), 'An Index of Assembly Dissolution Powers', Comparative Political Studies, 49(4): 427-56.

Grimmer, J. and Stewart, B. M. (2013), 'Text as data: The promise and pitfalls of automatic content analysis methods for political texts’, Political Analysis, 21(3): 267-97. 
Grofman, B. and Van Roozendaal, P. (1997), 'Review Article : Modelling Cabinet Durability and Termination', British Journal of Political Science, 27(3): 419-51.

Hellwig, T. (2012), 'Constructing Accountability: Party Position Taking and Economic Voting’, Comparative Political Studies, 45(1): 91-118.

Hix, S., Noury, A. and Roland, G. (2006), 'Dimensions of Politics in the European Parliament', American Journal of Political Science, 50(2): 494-520.

Hjorth, F. et al. (2015), 'Computers, coders, and voters: Comparing automated methods for estimating party positions’, Research \& Politics, 2(2): 1-9.

Hönnige, C. (2009), 'Die Vertrauensfrage als Instrument der Agendakontrolle', in S. Ganghof, C. Hönnige, and C. Stecker (ed.) Parlamente, Agendasetzung und Vetospieler. Festschrift für Herbert Döring. (Wiesbaden: VS Verlag für Sozialwissenschaften): 25-39.

Huber, J. D. (1996), 'The Vote of Confidence in Parliamentary Democracies', American Political Science Review, 90(2): 269-82.

Hug, S. (2010), 'Selection effects in roll call votes', British Journal of Political Science, 40(1): 225-35.

King, G. et al. (1990), 'A unified model of cabinet dissolution in parliamentary democracies', American Journal of Political Science, 34(3): 846-71.

Lauderdale, B. E. and Herzog, A. (2016), 'Measuring political positions from legislative speech', Political Analysis, 24(3): 374-94.

Laver, M. (2003), 'Government Termination', Annual Review of Political Science, 6(1): 2340 .

Laver, M. and Benoit, K. (2002), 'Locating TDs in policy spaces: the computational text analysis of Dáil speeches’, Irish Political Studies, 17(1): 59-73.

Laver, M., Benoit, K. and Garry, J. (2003), 'Extracting Policy Positions from Political Texts Using Words as Data', American Political Science Review, 97(2): 311-31.

Laver, M., Benoit, K. and Sauger, N. (2006), 'Policy Competition in the 2002 French Legislative and Presidential Elections', European Journal of Political Research, 45(4): 66797.

Laver, M. and Shepsle, K. A. (1996), Making and Breaking Governments. Cabinets and Legislatures in Parliamentary Democracies (Cambridge: Cambridge University Press).

Laver, M. and Shepsle, K. A. (1998), 'Events, Equilibria, and Government Survival', American Journal of Political Science, 42(1): 28-54.

Lucas, C., Nielsen, R. A., Roberts, M. E., Stewart, B. M., Storer, A. and Tingley, D. (2015), 'Computer-assisted text analysis for comparative politics', Political Analysis, 23(2): 254-77.

Lupia, A. and Strøm, K. (1995), 'Coalition Termination and the Strategic Timing of Parliamentary Elections’, American Political Science Review, 89(3): 648-65.

Martin, L. W. and Vanberg, G. (2008), 'Coalition Government and Political Communication', Political Research Quarterly, 61(3): 502-16. 
Niclauß, K. (2007), 'Echte und auflösungsorientierte Vertrauensfrage. Eine Replik auf Stefan Ulrich Pieper in Heft 2/2007 der ZParl’, Zeitschrift für Parlamentsfragen, 38(3): 667-8.

Poole, K. T. and Rosenthal, H. (1985), ‘A Spatial Model for Legislative Roll Call Analysis', American Journal of Political Science, 29(2): 357-84.

Proksch, S.-O. and Slapin, J. B. (2012), 'Institutional Foundations of Legislative Speech', American Journal of Political Science, 56(3): 520-37.

Proksch, S.-O. and Slapin, J. B. (2015), The Politics of Parliamentary Debate: Parties, Rebels, and Representation (Cambridge: Cambridge University Press).

Quinn, K. M., Monroe, B. L., Colaresi, M., Crespin, M. H. and Radev, D. R. (2010), 'How to analyze political attention with minimal assumptions and costs', American Journal of Political Science, 54(1): 209-28.

Roberts, M. E. et al. (2014), 'Structural topic models for open-ended survey responses', American Journal of Political Science, 58(4): 1064-82.

Saalfeld, T. (2008), 'Institutions, Chance, and Choices: The Dynamics of Cabinet Survival', in K. Strøm, W. C. Müller and T. Bergman (ed.) Cabinets and Coalition Bargaining. The Democratic Life Cycle in Western Europe. (Oxford: Oxford University Press): 327-68.

Saalfeld, T. (2013), 'Economic Performance, Political Institutions and Cabinet Durability in 28 European Parliamentary Democracies, 1945-2011', in W.C. Müller and H. Narud (ed.) Party Governance and Party Democracy. (New York: Springer): 51-79.

Schleiter, P. and Morgan-Jones, E. (2009), 'Constitutional Power and Competing Risks: Monarchs, Presidents, Prime Ministers, and the Termination of East and West European Cabinets', American Political Science Review, 103(3): 496-512.

Schwemmer, C. (2018), 'stminsights: A 'Shiny' Application for Inspecting Structural Topic Models’. R package version 0.1.2, https://github.com/methodds/stminsights.

Sieberer, U. (2006), 'Party unity in parliamentary democracies: A comparative analysis', Journal of Legislative Studies, 12(2): 150-78.

Slapin, J. B. and Proksch, S.-O. (2008), 'A Scaling Model for Estimating Time-Series Party Positions from Texts’, American Journal of Political Science, 52(3): 705-22.

Strøm, K. (1990), 'A Behavioral Theory of Competitive Political Parties’, American Journal of Political Science, 34(2): 565-98.

Volkens, A., Lehmann, P., Matthiess, T., Merz, N., Regel, S. and Weßels, B. (2017), 'The Manifesto Data Collection. Manifesto Project (MRG/CMP/MARPOR)'. Version 2017b.

Warwick, P. V. (1992), 'Economic Trends and Government Survival in West European Parliamentary Democracies’, American Political Science Review, 86(4): 875-87.

Warwick, P. V. (1994), Government Survival in Parliamentary Democracies (Cambridge: Cambridge University Press). 


\section{APPENDIX}

\section{A) FREX terms extracted from 20 topics}

\begin{tabular}{|c|c|}
\hline Topics in LP 14 & FREX terms \\
\hline Agriculture & $\begin{array}{l}\text { dat,verbraucherschutz,künast,bauern,landwirt,landwirtschaft,landwirtschaftlichen,v } \\
\text { erbrauch,agrarpolitik,tier,bse,funk,ländlichen,naturschutz,produkt,verbraucherinne } \\
\text { n,agenda,lebensmittel,betrieb,wald,landwirten,fleisch,verbrauchern,gemeinschaftsa } \\
\text { ufgab,ökologischen,staatsziel,natur,rindfleisch,ministerin,landwirtschaftsminist, }\end{array}$ \\
\hline Cultural & $\begin{array}{l}\text { tourismus,sport,engag,verein,stiftungen,ehrenamtlich,film,anfrag,kulturpolitik,bran } \\
\text { ch,ehrenamt,expo,kultur,enquete- } \\
\text { kommiss,tourismuswirtschaft,ausschuss,rahmenbedingungen,brähmig,stiftungsrech } \\
\text { t,bürgerschaftlich,urlaub,vereinen,hinsken,ausland,euro,schiff,freiwilligen,ehrenam } \\
\text { tlichen,ostse,well, }\end{array}$ \\
\hline Residual & $\begin{array}{l}\text { muß, ausschuß,schluß,bißchen,läßt,bewußt,müßten,sogenannten,müßte,opfer,beschl } \\
\text { uß,rotgrün,prozeß,anlaß,sogenannt,mußten,stiftung,mußt,entschädigung,ddr,zwang } \\
\text { sarbeit,abschluß,rotgrünen,einfluß,kompromiß, betroffenen,paßt,urteil,lasten,unrech } \\
\text { t, }\end{array}$ \\
\hline Transportation & $\begin{array}{l}\text { bahn,transrapid,schien,wohnungsbau,wohnungen,verkehr,verkehrspolitik,mieter,str } \\
\text { eck,ag,straße,wohngeld,verkehrsträg,bundesverkehrswegeplan,bau,mehdorn,bodew } \\
\text { ig,wohnungsunternehmen,netz,investitionen,güterverkehr,mobilität,db,mietrecht,ve } \\
\text { rkehrsinfrastruktur,bauwirtschaft,verkehrsminist,hamburg,wohnungspolitik,ausbau, }\end{array}$ \\
\hline Defense/International & $\begin{array}{l}\text { kosovo,mazedonien,milosev,terrorismus,nato,afghanistan,krieg,jugoslawien,osz,na } \\
\text { tionen,vereinten,russland,militärisch,menschenrecht,frieden,stabilitätspakt,rußland, } \\
\text { balkan,militärischen,außenminist,außenpolitik,flüchtling,humanitär,auswärtigen,sta } \\
\text { aten,menschenrechtsverletzungen,tschetschenien,region,israel,konflikt, }\end{array}$ \\
\hline Development & $\begin{array}{l}\text { entwicklungszusammenarbeit,entwicklungspolitik,afrika,entwicklungsländ,entwick } \\
\text { lungsländern,globalisierung,nachhaltigkeit,global,nachhaltig,klimaschutz,konferen } \\
\text { z,internationalen,weltweit,globalen,international,ökologisch,kuba,welt,handel,entw } \\
\text { icklung,nachhaltigen,umwelt,armut,instrument,weltbank,armutsbekämpfung,intern, } \\
\text { nichtregierungsorganisationen,iwf,ärmsten, }\end{array}$ \\
\hline Defense/Interior & $\begin{array}{l}\text { bundeswehr,scharp,verteidigungsminist,soldaten,wehrpflicht,streitkräft,wehrbeauft } \\
\text { ragten,verteidigungshaushalt,breuer,verteidigung,soldatinnen,zivilen,sicherheitspol } \\
\text { itik,dienst,militärischen,ausrüstung,einsatz,arme,militärisch,trupp,bundesminist,ein } \\
\text { sätz,bundesverteidigungsminist,führung,zivil,verteidigungsausschuss,bundeswehrr } \\
\text { eform,rühe,sicherheitspolitischen,aufgaben, }\end{array}$ \\
\hline Interior & $\begin{array}{l}\text { zuwanderung,bundesinnenminist,schili,innenminist,demokrati,ausländer,petitionsa } \\
\text { usschuss, westerwell,rechtsextremismus,gewalt,petitionen,grundgesetz,marschewsk } \\
\text { i,integr,staatsangehörigkeit,polizei,npd,staatsangehörigkeitsrecht,rechtsstaat,krimin } \\
\text { alität,ausländisch,inner,verfassungsschutz,volk,toleranz,straftaten,bürgerinnen,part } \\
\text { ei,bürger,gesellschaft, }\end{array}$ \\
\hline Health & $\begin{array}{l}\text { gesundheitswesen,versicherten,krankenkassen,patienten,gesundheitspolitik,kranke } \\
\text { nversicherung,ärzte,versorgung,budget,pflegeversicherung,budgetierung,patientinn } \\
\text { en,gesundheitssystem,arzneimittel,zuzahlungen,medizinisch,arzt,kranken,gesetzlic } \\
\text { hen,chronisch,kassen,leistungen,seehof,system,gesundheitsreform,qualität,medizini } \\
\text { schen,gkv,risikostrukturausgleich,pflege, }\end{array}$ \\
\hline Reunification & $\begin{array}{l}\text { ostdeutschen,ost,osten,ostdeutschland,einheit,berlin,kommunen,gemeinden,aufbau, } \\
\text { west,ostdeutsch,bundesländern,bundesländ,westen,kommunalen,denkmal,stadt,sac } \\
\text { hsen- } \\
\text { anhalt,mahnmal,ddr,solidarpakt,neuen,sachsen,bonn,städte,bund,kommunal,schwa } \\
\text { nitz,brandenburg,länder, }\end{array}$ \\
\hline Family & $\begin{array}{l}\text { frauen,famili,kindern,kinder,familienpolitik,eltern,erziehung,behinderten,familien, } \\
\text { männer,männern,behindert,armut,kind,beruf,gleichstellung,erziehungsgeld,gewalt, }\end{array}$ \\
\hline
\end{tabular}




\begin{tabular}{|c|c|}
\hline & $\begin{array}{l}\text { zivildienst,vereinbarkeit,senioren,sozialhilf,kindergeld,bergmann,ehe,betreuung,rec } \\
\text { htsanspruch,erziehungsurlaub,schwerbehindert,ix, }\end{array}$ \\
\hline Environmental & $\begin{array}{l}\text { kernenergi,trittin,energiepolitik,ausstieg,energien,atomenergi,untersuchungsaussch } \\
\text { uss,erneuerbaren,umweltpolitik,merkel,kohl,kernkraftwerk,strom,umweltminist,tra } \\
\text { nsport,anlagen,energieversorgung,gorleben,kraft-wärme- } \\
\text { kopplung,erneuerbar,müller,energi,klimaschutz,atomkraftwerk,atomausstieg,huste } \\
\text { dt,endlag,parteiengesetz,nutzung,palla, }\end{array}$ \\
\hline Finance/Budget & $\begin{array}{l}\text { haushalt,bundeshaushalt,einzelplan,ausgaben,etat,sparen,schulden,kürzungen,milli } \\
\text { arden,gekürzt,finanzminist,haushaltsentwurf,millionen,eichel,mittel,haushaltsberat } \\
\text { ungen,höhe,investitionen,bundesfinanzminist,austermann,kürzen,milliard,waigel,ei } \\
\text { nsparungen,finanzplanung,erhöht,haushaltspolitik,erhöhung,sparpaket,koalit, }\end{array}$ \\
\hline Procedural Statements & $\begin{array}{l}\text { staatssekretärin,staatssekretär,staatsminist,post,bundesministerium,bekannt,gespräc } \\
\text { h,antwort,ag,informationen,tschechischen,beantworten,rahmen,standort,bestätigen, } \\
\text { beantwortet,beantwortung,entsprechenden,bundesminist,prüfung,entsprechend,auss } \\
\text { ag,zuständigen,fragestund,geprüft,prüfen,abgeordnet,zuständig,erfolgt,auffassung, }\end{array}$ \\
\hline Tax Policy & $\begin{array}{l}\text { steuerreform,mittelstand,steuern,steuerpolitik,steuer,wachstum,ökosteuer,senkung, } \\
\text { entlastung,entlastet,eichel,wirtschaftspolitik,besteuerung,merz,senken,finanzpolitik } \\
\text {,kapitalgesellschaften,euro,lohnnebenkosten,lafontain,unternehmensteuerreform,un } \\
\text { ternehmen,spitzensteuersatz,brüderl,steuerlich,steuererhöhungen,konjunktur,mehr } \\
\text { wertsteu,steuersätz,pfennig, }\end{array}$ \\
\hline Social/Labor Market & $\begin{array}{l}\text { riester,rent,arbeitslosen,arbeitsmarktpolitik,rentenreform,rentenversicherung,arbeit } \\
\text { slos,arbeitnehm,arbeitgeb,arbeitsmarkt,rentner,arbeitslosigkeit,beschäftigung,bund } \\
\text { esanstalt,gewerkschaften,altersvorsorg,renten,schwarzarbeit,arbeitslosenhilf,arbeitn } \\
\text { ehmerinnen,arbeitnehmern,beschäftigten,laumann,arbeit,sozialversicherung,sozialp } \\
\text { olitik,arbeitsminist,demographischen,sozialhilf,arbeitsplätz, }\end{array}$ \\
\hline Education & $\begin{array}{l}\text { hochschulen,bildung,bulmahn,bafög,ausbildung,studierenden,schulen,jugendlichen } \\
\text {,weiterbildung,ausbildungsplätz,bildungspolitik,studium,jugendlich,studenten,prog } \\
\text { ramm,internet,sofortprogramm,jungen,wirtschaft,lernen,beruflichen,jung,forschung } \\
\text {,förderung,beruflich,unternehmen,rüttger,studierend,bafög-reform,schule, }\end{array}$ \\
\hline EU Policy & $\begin{array}{l}\text { nizza,mitgliedstaaten,europäisch,europa,europäischen,konvent,erweiterung,gipfel,t } \\
\text { ürkei,union,polen,präsidentschaft,osterweiterung,vertrag,regierungskonferenz,eu,k } \\
\text { ommiss,europapolitik,rat,außenminist,beitritt,brüssel,österreich,nationalen,charta,i } \\
\text { ntegr,bundeskanzl,agenda,amsterdam,helsinki, }\end{array}$ \\
\hline Legislation & $\begin{array}{l}\text { gesetzentwurf,entwurf,regelung,gesetz,anhörung,änderung,verfahren,bundesrat,ger } \\
\text { icht,gei,bundesverfassungsgericht,regelungen,justiz,praxi,gesetzgeb,beratungen,zus } \\
\text { timmen,vorliegenden,richter,rechtsprechung,änderungen,beratung,lesung,urteil,bgb } \\
\text {,eingebracht,rechtsausschuss,bundesr,reform,geregelt, }\end{array}$ \\
\hline Genetic engineering & $\begin{array}{l}\text { stammzellen,embryonen,gentechnik,ethisch,forschung,embryonalen,embryo,mensc } \\
\text { hlichen,menschlich,wissenschaft,menschenwürd,import,pid,mensch,gentechnisch, } \\
\text { wissenschaftlich,genetisch,ethischen,leben,grundlagenforschung,kirch,krankheiten, } \\
\text { patent,embryonenschutzgesetz,verbot,medizin,gesundheit,präimplantationsdiagnos } \\
\text { tik,biotechnologi,schutz, }\end{array}$ \\
\hline Topics in LP 15 & FREX terms \\
\hline Cultural Diplomacy & $\begin{array}{l}\text { dat,de,kultur,kulturpolitik,ir,un,is,en,sprach,kulturellen,kulturell,deutsch- } \\
\text { französisch,französisch,be,deutsch,ge,ei,kulturen,sprachen,lernen,na,ausland,gen,fr } \\
\text { ankreich,vielfalt,einigkeit,franzosen,minderheiten,stück,freundschaft, }\end{array}$ \\
\hline Procedural Statements & $\begin{array}{l}\text { staatssekretär,bekannt,staatssekretärin,bundesministerium,verfahren,folgt,antwort,p } \\
\text { rüfung,bundesanstalt,staatsministerin,richtlini,abgeordnet,staatsminist,well,beantw } \\
\text { ort,finanzplatz,prüfen,beantwortet,beantworten,erfolgt,bundesbank,ag,bestätigen,p } \\
\text { ost,genannten,sachverhalt,hinsichtlich,erlass,entsprechenden,vorliegen, }\end{array}$ \\
\hline Commemoration & $\begin{array}{l}\text { geschicht,berlin,partei,demokrati,merkel,parteien,gesellschaft,westerwell,juden,mü } \\
\text { ntefer,bundeskanzl,volk,opfer,freiheit,spd,enquete- } \\
\text { kommiss, antisemitismus,leben,stund,auseinandersetzung,jüdischen,israel,demokrat } \\
\text { ischen,ddr,gerechtigkeit,grundgesetz,ordnung,wahrheit,abgeordnet,nie, }\end{array}$ \\
\hline
\end{tabular}




\begin{tabular}{|c|c|}
\hline Defense/Interior & $\begin{array}{l}\text { bundeswehr,wehrpflicht,soldatinnen,soldaten,einsätz,streitkräft,dienst,einsatz,verte } \\
\text { idigungsminist,auslandseinsätz,wehrbeauftragten,auslandseinsätzen,verteidigung,f } \\
\text { ührung,einsätzen,trupp,aufgaben,arme,verteidigungsausschuss,struck,militärisch,au } \\
\text { srüstung,richtlinien,zivilen,minist,ausbildung,transform,militärischen,inneren,siche } \\
\text { rheitspolitisch, }\end{array}$ \\
\hline Social/Labor Market & $\begin{array}{l}\text { arbeitnehm,kündigungsschutz,handwerk,arbeitsmarkt,arbeitslosigkeit,arbeitslosen, } \\
\text { gewerkschaften,ausbildungsplätz,mittelstand,clement,arbeitgeb,gesundheitswesen, } \\
\text { betrieblich,beschäftigung,betrieb,rent,patienten,arbeitslos,rentenversicherung,rentn } \\
\text { er,hartz,ausbildung,arbeitsplätz,krankenversicherung,beiträg,beschäftigten,arbeits } \\
\text { marktpolitik,gesetzlichen,mitbestimmung,krankenkassen, }\end{array}$ \\
\hline Federalism & $\begin{array}{l}\text { kommunen,bundesministerin,gemeinden,kommunalen,staatssekretärin,parl,sicheru } \\
\text { ng,städte,gesundheit,kommunal,bund,caspers- } \\
\text { merk,bundesagentur,regionen,marion,stadt,sozial,bundesländern,staatssekretär,pro } \\
\text { gramm,sachsen,länder,kommiss,ort,baukultur,bundesländ,aufgaben,sgb,stiftung,län } \\
\text { dern, }\end{array}$ \\
\hline Inner Security & $\begin{array}{l}\text { bundesinnenminist,untersuchungsausschuss,schili,zuwanderung,zuwanderungsgese } \\
\text { tz,schwarzarbeit,innenminist,sicherheitsbehörden,bosbach,bundeskriminalamt,poli } \\
\text { zei,ausländer,terrorismus,bundesgrenzschutz,integr,sicherheit,koschyk,kriminalität, } \\
\text { innenausschuss,bekämpfung,terroristisch,wiefelspütz,amt,beamten,innenpolitik,inn } \\
\text { er,bka,inneren,septemb,grundgesetz, }\end{array}$ \\
\hline Education & $\begin{array}{l}\text { hochschulen,forschung,bulmahn,bildung,wissenschaft,studierenden,tauss,bafög,inn } \\
\text { ov,studiengebühren,innovationen,universitäten,studium,wissenschaftl,wettbewerb,f } \\
\text { orschungseinrichtungen,forschungsförderung,eigenheimzulag,bund,reich,biotechno } \\
\text { logi,nanotechnologi,klonen,forschungspolitik,investieren,1998,programm,studente } \\
\text { n,pakt,raumfahrt, }\end{array}$ \\
\hline Development & $\begin{array}{l}\text { entwicklungszusammenarbeit,afrika,entwicklungspolitik,simbabw,entwicklungslän } \\
\text { dern,entwicklungsländ,afrikanischen,armut,aid,armutsbekämpfung,häfen,kongo,we } \\
\text { ltweit,international,sudan,entwicklungshilf,zusammenarbeit,hilf,konferenz,darfur,g } \\
\text { lobal,internationalen,hunger,bekämpfung,südafrika,lateinamerika,entschuldung,hiv } \\
\text {,staaten,unterstützen, }\end{array}$ \\
\hline Family & $\begin{array}{l}\text { jugendlichen,eltern,kinder,kindern,jugendlich,frauen,familien,kind,famili,betreuun } \\
\text { g,beruf,kinderbetreuung,jungen,männer,jung,prävention,familienpolitik,zivildienst, } \\
\text { jugendhilf,alter,erziehung,ausbildung,gesellschaft,freiwilligendienst,ganztagsschul } \\
\text { en,schule,leben,behindert,behinderungen,jugend, }\end{array}$ \\
\hline Environment I & $\begin{array}{l}\text { erneuerbaren,emissionshandel,energien,klimaschutz,umweltpolitik,erneuerbar,eeg, } \\
\text { energiepolitik,trittin,reach,kioto- } \\
\text { protokol,ökologisch,industri,ökosteuer,energi,instrument,strom,kernenergi,kosten,t } \\
\text { onnen,anlagen,umwelt,umweltschutz,energieversorgung,arbeitsplätz,allokationspla } \\
\text { n,wirtschaft,biomass,nutzung,umweltminist, }\end{array}$ \\
\hline Environment II & $\begin{array}{l}\text { gentechnik,naturschutz,tourismus,bürokrati,gentechnisch,grüne,grünen,nutzung,um } \\
\text { welt,pflanzen,natur,nachhaltigkeit,bürokratieabbau,antrag,daten,wald,nachhaltig,ho } \\
\text { lz,bedeutung,fdp,markt,band,national,tierversuch,forderung,schleswig- } \\
\text { holstein,verändert,forderungen,produkt,tierschutz, }\end{array}$ \\
\hline Foreign Policy & $\begin{array}{l}\text { menschenrecht,china,russland,ukrain,russischen,iran,tschetschenien,menschenrecht } \\
\text { sverletzungen,waffenembargo,putin,aufhebung,folter,konflikt,kolumbien,waffen,be } \\
\text { ziehungen,russisch,demokrati,wahlen,staaten,bundeskanzl,fischer,dialog,lösung,pa } \\
\text { rlamentari,demokratisch,friedlich,partnerschaft,vereinten,export, }\end{array}$ \\
\hline Tax Policy & $\begin{array}{l}\text { eichel,steuerreform,schulden,steuern,wachstum,bundesfinanzminist,merz,gewerbes } \\
\text { teu,finanzminist,finanzpolitik,milliarden,neuverschuldung,einnahmen,wachstumsp } \\
\text { akt,eigenheimzulag,subventionsabbau,steuerpolitik,steuererhöhungen,stabilität,vert } \\
\text { rauen,steuereinnahmen,nachtragshaushalt,subventionen,haushalt,vorschläg,steuerre } \\
\text { cht,ausgaben,gemeinden,bundeshaushalt,steuer, }\end{array}$ \\
\hline Budget & $\begin{array}{l}\text { einzelplan,sport,haushalt,etat,kürzungen,bundeshaushalt,ausgaben,millionen,euro,h } \\
\text { aushaltsausschuss,haushaltsberatungen,mittel,gekürzt,minderausgab,kürzung,geld, } \\
\text { bundesrechnungshof,2005,kürzen,öffentlichkeitsarbeit,einsparungen,milliarden,20 } \\
\text { 04,haushaltsentwurf,austermann,2006,sparen,höhe,ministerium,titel, }\end{array}$ \\
\hline
\end{tabular}




\begin{tabular}{|l|l|}
\hline EU Policy & $\begin{array}{l}\text { türkei,europa,verfassung,europäisch,europäischen,mitgliedstaaten,konvent,erweiter } \\
\text { ung,rat,union,eu,beitritt,brüssel,kommiss,verfassungsvertrag,polen,verhandlungen, } \\
\text { prozess,staaten,parlament,nationalen,gemeinsamen,außen,mehrheit,bürgerinnen,gi } \\
\text { pfel,regierungskonferenz,kopenhagen,integr,aufnahm, }\end{array}$ \\
\hline Defense/International & $\begin{array}{l}\text { irak,nato,afghanistan,mandat,krieg,militärisch,terrorismus,nationen,freedom,kabul, } \\
\text { endur,vereinten,frieden,außenpolitik,kosovo,massenvernichtungswaffen,militärisch } \\
\text { en,amerika,amerikanischen,kunduz,außenminist,internationalen,mazedonien,kampf } \\
\text {,saddam,vereinigten,region,amerikan,international,einsatz, }\end{array}$ \\
\hline Agriculture & $\begin{array}{l}\text { landwirt,landwirtschaft,bauern,verbraucherschutz,verbrauch,künast,verbraucherinn } \\
\text { en,agrarpolitik,produkt,lebensmittel,landwirtschaftlichen,ernährung,verbraucherpol } \\
\text { itik,betrieb,landwirten,markt,goldmann,ministerin,ländlichen,modul,verbrauchern, } \\
\text { musik,tierschutz,tier,qualität,landwirtschaftlich,reform,dr,geehrt,krankenversicheru } \\
\text { ng, }\end{array}$ \\
\hline Justice & $\begin{array}{l}\text { gesetzentwurf,entwurf,bundesverfassungsgericht,regelung,opfer,gesetz,täter,gesetz } \\
\text { geb,regelungen,anhörung,gericht,urteil,verfahren,praxi,sicherungsverwahrung,bun } \\
\text { desrat,fällen,bundesr,änderungen,schutz,regeln,vorliegenden,straftaten,missbrauch, } \\
\text { gesetzlich,bürger,fälle,geregelt,änderung,uhr, }\end{array}$ \\
\hline Transportation & $\begin{array}{l}\text { schien,stolp,bahn,bundesverkehrswegeplan,maut,ostdeutschland,ost,verkehrsinfrast } \\
\text { ruktur,straße,verkehr,infrastruktur,verkehrspolitik,ag,investitionen,osten,projekt,str } \\
\text { aßen,bahnreform,db,minist,bau,ausbau,eu-osterweiterung,streck,lkw- } \\
\text { maut,verkehrsträg,netz,milliarden,bauwirtschaft,eigenheimzulag, }\end{array}$ \\
\hline
\end{tabular}

